DOI 10.31558/2519-2949.2020.2.20

УДК 327.3:329.1

ORCID ID: https://orcid.org/0000-0002-1089-9019

Якимчук М. М., Національний університет «Острозька академія»

\title{
ЧИННИКИ ЗРОСТАННЯ ПОПУЛЯРНОСТІ ЄВРОСКЕПТИЦИЗМУ В ЄС
}

У статті визначено та проаналізовано чинники, щзо вплинули на появу, поширення та активізацію євроскептицизму. Зокрема, охарактеризовано умови формування опозиції до $С С$, визначено основні каталізатори зростання недовіри до організації. А також простежено взаємозв'язок між євроскептицизмом та кризовими явищами у ЄС і який вони вплив здійснюють на формування думки населення щзодо політики організації.

За результатами проведеного дослідження причини поширення ідей євроскептицизму умовно можна розділити на кілька груп. Опозиція до СС з'явилася разом із появою перших ознак формування організачіï, проте не була вираженою. Упродовж ХХ століття, незважаючи на певні економічні проблеми, рівень підтримки СС стабільно зростав аж до 2007 року. Однак, згодом через прямий та опосередкований вплив внутрішніх та зовнішніх факторів, опозиція до Свропейського Союзу почала набирати обертів. У результаті иъього з латентного стану євроскептицизм перейшов до практичного, як наслідок було запущено безпрецеедентний процес - вихід Великої Британї з організації.

Проаналізувавии статистичні показники позиції громадян щуодо СС, а також внутрішньополітичну ситуацію в організації, можна зробити висновок, щуо не лише суттєві економічні та сочіальні проблеми сприяли зростанню євроскептицизму. На зростання опозиції до Свропейського Союзу більшою мірою вплинула діяльність популістичних партій та рухів з Центрально-Східної Свропи, які почали приєднуватися до організації після 2004 року. Свроскептики з нової Свропи, об’ єднавшись з антиєвропеїстами зі Сполученого Королівства, скориставиись складним економічним становищем в організації та міграційними викликами, провели вдалу інформаційну кампанію проти СС. У результаті иъього довіра до Союзу суттєво впала і громадяни сумніваються в ефективності роботи організації.

Ключові слова: євроскептицизм, популізм, економічна криза, міграційна криза, Брекзит.

Постановка проблеми. Європейський Союз постійно змінювався юридично, інституційно, політично, економічно та культурно. І на ці зміни впливала низка факторів, які спровокували появу та поширення євроскептичних настроїв, як серед політиків, так і серед населення. Не обов'язково усі ці фактори негативно позначалися на СС чи державах-членах, але за допомогою політики самого ЄC, стратегій та дій національних урядів, а також враховуючи тенденції на міжнародній арені, Свропа стикнулася з новою проблемою, яка не про економічний розвиток чи фінансову незалежність, а про самоідентифікацію європейців, про їх цивілізаційну та національну приналежність. I щоб зрозуміти, куди рухається Європа, варто з'ясувати, що цьому передувало. Тому необхідно визначити усі фактори, які опосередковано чи прямо вплинули та впливають на зростання опозиційних настроїв у СС від початку його заснування і до сьогодні.

Аналіз останніх досліджень та публікацій. Першими, хто намагався визначити причини опозиції до СС, стали А. Щербяк та П. Таггарт [17]. Вони розглядали це питання крізь призму партійного євроскептицизму, зазначаючи, що саме партії через свою діяльність стали рушійною силою скептицизму до ЄС. Більш детально проаналізували ймовірні причини євроскептицизму Л. Хуг та Г. Маркс, зазначаючи, що рушієм євроскептицизму є взаємозв'язок національної ідентичності та економічних факторів [7]. Власний підхід до трактування євроскептицизму розробив П. де Вільд, який розділив прояви євроскептицизму на чотири типи за суб'єктами: позиція громадян, позиції політичних партій, громадські обговорення та політична система СС. I відповідно до цих типів визначив причини опозиції до ЄС [3]. Досліджуючи євроскептицизм, учені досить часто використовували метод case-study. Грунтовне дослідження причин євроскептицизму провів Д. Вальред, порівнявши причини та прояви євроскептицизму у Німеччині та Великій Британії [22]. Ознайомившись із працями учених, варто виокремити одну важливу спільну ідею. 
Вони стверджують, що певний рівень опозиції до європейської інтеграції завжди був серед державчленів та держав-сусідів $\mathrm{CC}$, однак нового поштовху він почав набирати лише в останньому десятилітті через низку викликів, з яким стикнувся $С \mathrm{C}$, а саме через економічну та міграційну кризи, при цьому включаючи фактор національної ідентичності. Проте відкритим питанням залишається, чи це твердження відповідає дійсності. Тому метою дослідження є проаналізувати політичні умови появи та поширення євроскептицизму. Зокрема, необхідно охарактеризувати політичну ситуацію, у якій був створений та сформувався $\mathrm{CC}$ та, відповідно, опозиція до нього, визначити реальний вплив економічної та міграційної криз на рівень євроскептицизму, а також врахувати роль інших опосередкованих факторів на розвиток євроскептицизму.

Виклад основного матеріалу дослідження. Першим кроком до формування Європейського Союзу став Брюссельський договір 1948 року, відповідно до якого Велика Британія, Франція та країни Бенілюксу погодилися на військову кооперація на противагу можливій агресії, як із боку Німеччини, так із боку Радянського Союзу. Наступним кроком стало заснування Свропейської спільноти з вугілля та сталі, щоб посилити співробітництво між державами Європи, особливо з Німеччиною з метою уникнення конфліктів [16]. У 1957 році підписали ще два основоположні договори, які передбачали поглиблення економічної співпраці [20]. Тобто усі документи мали на меті гарантувати безпеку та мінімізувати появу конфлікту принаймні у Західній Європі. Тому метою створення ЄС була гарантія безпеки через співробітництво. Але після зникнення загрози процес інтеграції продовжувався, хоча вже без конкретної цілі, що призвело до проблем. Свропейці не погодили спільне бачення подальшої інтеграції, що дозволило кожній державі ЄС сформувати власне розуміння майбутнього $Є С$, яке різнилося. Тому між державами-членами виникає латентний конфлікт щодо інтерпретації майбутнього організації: одні виступають за посилення інтеграції, інших влаштовує існуючий формат співробітництва. Саме ця ситуація стала першим проявом євроскептицизму.

Крім того, у процесі інтеграції засновники ЄС допустили ще одну помилку. Протягом багатьох років рішення у СС приймали політики різного рівня, дипломати, урядовці, національні уряди, однак, не громадяни. Через це європейські урядовці фактично втратили зв'язок з населенням СС і могли приймати важливі рішення, не залучаючи їх до процесу [20]. Не дивно, що відповідно до статистичних показників за 2015 рік найбільший рівень євроскептицизму спостерігається саме серед громадян старше 55 років, тобто тих, які були свідками усього процесу інтеграції [24]. Так як увесь початковий етап інтеграційного процесу пройшов 3 мінімальним залученням громадян, (лише у 1979 році громадяни отримали змогу голосувати), опосередковано впливаючи на політику ЄС, їм складно довіряти цій структурі.

Ще однією причиною євроскептицизму була позиція Великої Британії та її політика. Сполучене Королівство завжди було одним із найпотужніших осередків євроскептицизму. Якщо розглядати відносин $Є С$ та Великої Британії, то можна зробити висновок, що ЄС для Сполученого Королівства завжди був запасним варіантом, а євроскептицизм - невід'ємним елементом британської політики. Причинами такої політики є ознаки британського імперіалізму, які сформувалися упродовж тривалого лідерства у XX столітті. Крім того, як зауважує Т. Райс, з самого початку формування організації у Великій Британії реалізовувалася потужна інформаційна кампанія проти європейської інтеграції [16]. I приєднання Британії до ЄС не змінило цього. Як наслідок, британці зробили свій вибір не на користь ЄС. Процес Брекзиту розпочав дезінтеграційний процес у ЄС.

До факторів, які сприяють активізації опозиції до СС, варто віднести діяльність інституцій ЄС. Процес формування інституцій СС був не плановим, а спонтанним кроком у відповідь на ситуацію, що склалася. Тому розробляти чіткий механізм розподілення функцій та впливу не було часу, що згодом негативно вплинуло на інтеграційний процес [4]. Досить часто роботу інституцій ЄС піддають критиці. Проблема у тому, що населення не завжди розуміє, які питання належать до компетенції національних урядів, а які до ЄС. На це скаржиться і європейський омбудсмен Е. О'Рейлі [13]. Проблемою $є$ і те, що законодавчий акт проходить низку процедур та комітетів перш, ніж він буде затверджений. А увесь процес $є$ не зовсім прозорим. Громадяни не до кінця розуміють, як працює ЄС. I цей вакуум почали заповнювати національні ЗМІ, противники ЄС та популісти, які маніпулювали інформацією та фактами щодо членства в організації, що стало основною причинною поширення євроскептицизму. Зокрема, євроскептичні праві партії акцентують більше уваги на націоналізмі та міграції, коли євроскептичні ліві партії - на економічних питаннях. Тому потрібно детально розглянути ці, виокремлені євроскептичними партіями, аспекти ЄС через призму євроскептицизму. 
Ультраліві та популісти транслюють ідею, що національна ідентичність та європейська ідентичність - це абсолютно різні речі. Але варто зрозуміти, що європейська ідентичність набагато складніше поняття, яке включає у собі різні аспекти національної самоідентифікації представника 3 кожної країни, що ускладнює процес зближення. Відповідно до даних Євробарометру Європейської комісії все менше громадян ідентифікують себе відповідно до власної національної приналежності. 31999 по 2014 роки можна помітити зростання самоідентифікації населення як європейців, але після 2014 року ці показники знизилися. Стабільно зростають показники, відповідно до яких громадяни підтримують свою національну приналежність і в той же момент вважають себе європейцями понад 50\% [8].

Міграційна криза стала ще одним каталізатором євроскептицизму. Враховуючи високий рівень постійної конфліктогенності на Близькому Сході та в Північній Африці, кількість мігрантів 3 тих регіонів завжди була висока і постійно зростала. А з 2010 по 2014 роки кількість біженців досягнула до 1,4 мільйона і вже згодом перестала бути контрольованою [9]. Лише за один рік з 2014 по 2015 роки кількість мігрантів, яка прибувала морським шляхом, перевищала 1 мільйон. А за 2015 рік цей показник сягнув 1,82 мільйона [12]. Відповідно до Дублінських угод від 2003 року громадяни, які хочуть отримати притулок, можуть його попросити не в усіх країнах $\mathrm{CC}$, а лише в тої, у якій вперше перетнули кордон [2]. Основна проблема полягала у тому, що саме держави Середземномор'я прийняли переважну кількість мігрантів і саме вони намагалися врегулювати цю проблему. Однак, коли кількість мігрантів зростала, Італії та Іспанії складно було стабілізувати ситуацію. Франції та Німеччини ініціювали зміну системи квотування прийняття біженців, проте ця ідея неабияк обурила інші держави, особливо, Польщу, Угорщину, Словаччину, Чехію та Велику Британію [6]. Через маніпуляції та велику кількість біженців антиєвропейські настрої з новою силою активізувалися не тільки у державах, які прийняли мігрантів, а й у тих, які відмовилися це робити. Мігранти з Північної Африки та Близького Сходу потребували місця проживання, соціальних виплат, належного медичного забезпечення. Організувати такі умови могли лише виділяючи кошти з держбюджету, що не підтримувало місцеве населення. Незважаючи на відносно вороже налаштоване населення до біженців, громадяни висловлюють своє невдоволення саме щодо того, як $Є С$ врегульовував цю проблему, а не до мігрантів. Зокрема, 74\% громадян держав-членів ЄС не підтримують саме стратегію ЄС щодо врегулювання міграційної кризи [23].

$€$ твердження, що через біженців Європа стала одним із центрів терористичних атак. Дані опитувань, проведених у 2016 році, свідчать про те, що більшість громадян, а саме $59 \%$ вважають, що причиною терористичних атак $є$ міграційна криза, у Польщі та Угорщині цей показник становить понад 70\% [23]. Але цікавим виявилося дослідження Е. Ларсена, Д. Катсі, які, визначили, що позиція громадян до ЄС не змінюється після терористичних актів, громадяни не звинувачують ЄС у терористичних атаках. Однак, як зауважують самі автори, зв'язок між біженцями та терористичними атаками формують популістичні та євроскептичні партії, серед яких «Альтернатива для Німеччини», «Національний Фронт», «Рух 5 зірок» та низка інших [11].

Представники правих партій вважають, що найбільшою проблемою $Є С$ є економічне падіння. Починаючи з 60-их років ВВП держав-учасниць європейських спільнот зростав, окрім певних кризових періодів. Упродовж 80-их років у СС спостерігалося значне зростання ВВП, зниження рівня безробіття та інфляції. Після розпаду Радянського Союзу, фінансової кризи в Росії та коливання цін на нафту через вторгнення Іраку в Кувейт спостерігався певний економічний спад, особливо складною ситуація була у 1993 році. Але економіку вдалося стабілізувати, тому після запуску Єврозони з 1 січня 1999 року відбулося економічне зростання на 3,5\%, стабілізація ВВП та зниження безробіття [18]. Варто зазначити, що з 2000 року і до 2007 року ВВП у СС утримував стабільну ланку, навіть, не зважаючи на розширення у 2004 році. Щорічно економіка ЄС зростала від 1\% до 3\% [19]. Але фінансово-економічна криза 2008 року завдала суттєвої шкоди економіці ЄС, і ВВП впав на 4\% у 2009 році. Економічна криза спровокувала боргові кризи в Італії та Греції, а згодом і в Іспанії, що негативно позначилося на економічній ситуації у СС. Зона євро вважалася гордістю, однак деформації у світовій економіці показали усі недоліки такого етапу інтеграції. Зокрема, рівень безробіття досягнув майже $11 \%$ у 2013 році, коли до кризи він коливався у межах 7\%. Економічні показники стабілізувалися лише після 2015 року, але процес виявився незворотнім. Крім того, на той час $Є С$ вже стикнувся з новою кризою і новими проблемами, які тільки посили зростання євроскептичних настроїв. Безсумнівно таке економічне падіння сприяло розчаруванню у політиці ЄС. Рівень довіри до ЄС суттєво знизився з 57\% у 2007 році до $31 \%$ у 2012 році. А рівень недовіри до ЄС у 2012 році сягнув 60\% уперше за всю історію інтеграційного 
об’єднання, хоча згодом він знизився до 56\% [14]. Економічний фактор насправді нашкодив ЄС, чим вдало скористалися його противники.

Проте проблема не лише в економіці чи міграції. До причин активізації євроскептичних настроїв також можна віднести внутрішню політику СС та відносини між державами-членами. Зокрема, спостерігалися тісні відносини між британською Консервативною партією та деякими партіями у Центрально-Східній Європі, зокрема, польськими «Право та Справедливість» та «Об'єднана Польща», чеською «Громадянська демократична партія», іспанською «Вокс» та у минулому німецькою «Альтернатива для Німеччини». Вони входять в опозиційну групу в Свропарламенті «Європейських консерваторів та реформістів», яка у попередньому скликані 2014-2019 років, була найбільшою опозиційною групою. Після того як Британія залишила організацію, вони втратили свій вплив, поступившись іншій євроскептичній групі «ддентичність та демократія». Зростання опозиційний груп у Свропарламенті свідчить про політичну нестабільність в організації. Євроскептицизм став одним із факторів політичної кризи, а криза - це завжди перестановка сил.

Євроскептицизм може бути вигідним і не тільки опозиціонерам $Є С$, а й тим, хто не відіграє важливих та вирішальних ролей у ЄС. Ось чому більше антиєвропеїстів саме удержавах Центрально-Східної Європи, які не є лідерами в ЄС. Тому з метою зміщення держав-лідерів розпочинаються штучні рухи невдоволення проти європейської інтеграції. I допомагають їм у цьому зовнішні суб'єкти: уряди, політики, лобісти інших держав, наприклад, втручання суб'єктів РФ у справи Угорщини та Німеччини [10]. Втручання інших держав у справи держав-членів ЄС також можна вважати причиною євроскептицизму. Адже потужний актор на європейському континенті не вигідний державам-сусідам та особливо тим, хто також претендує на лідерство. Можливо, такої ситуації можна було б уникнути, якби СС мав відповідальну особу за весь процес інтеграціїпосаду президента. I справа навіть не в посаді, а увідсутності лідера, який буде нести відповідальність, приймати рішення та представляти ЄС на міжнародній арені. Наразі таку роль переважно виконують глави провідних держав. Проте для подальшої політичної інтеграції та протистоянню євроскептицизму цього недостатньо. Відсутність лідера в організації показує наскільки вразливою і слабкою вона може бути [21].

Про слабку внутрішню комунікацію свідчать двосторонні відносини між державами-членами ЄС. Відповідно до звіту Європейської Ради 3 питань зовнішніх відносин від 2018 року між державами спостерігаються досить слабкі двосторонні відносини [15]. Це підтверджує програма Європейської Ради «Коаліція ЄС» в основі якої лежить візуалізація соціологічного опитування близько 800 фахівців у сфері політики 328 держав-членів, яка показує, що між державами спостерігається високий рівень розділеності, втрачених можливостей та невикористаного потенціалу у співробітництві між урядами держав-членів. Виокремлено лише декілька потужних зв'язків між Польщею та Угорщиною, Чехією та Словаччиною, Швецією та Фінляндією, Німеччиною та Нідерландами, Німеччиною та Бельгією, Нідерландами та Бельгією, що свідчить про низький рівень внутрішньої комунікації, а це, своєю чергою, підвищує рівень внутрішнього непорозуміння та конфліктності [1]. Відсутність тісних двосторонніх відносин аж ніяк не сприяє поглибленню інтеграції, більше того, це загрожує ефективній реалізації уже існуючих проектів та політичній консолідації щодо важливих питань.

Останнє десятиліття ЄС ніяк не може розпочати працювати узвичному режимі, криза за кризою, проблеми різного характеру підривають економічну потужність та політичний вплив організації. I новий виклик - світова пандемія Covid-19 та іï наслідки - стане тією причиною, яка сприятиме не лише зростанню євроскептицизму, а й спричинить глобальну недовіру до ЄС. Ця криза показує, наскільки ЄС далекий від політичного союзу і що держава все-таки залишається основним суб'єктом в Європі, а ЄС лише організація. Тому байдужість Європарламенту на прохання Італії у допомозі першої необхідності повністю нівелює довіру до цієї інституції серед громадян Італії і без євроскептичних партій [5]. Майбутнє СС буде залежати від наслідків кризи, спричиненою Covid-19, та від ефективності реагування на цю кризу СC.

Причини появи та поширення євроскептицизму свідчать про те, що певний рівень опозиції завжди був до ідеї об'єднаної Європи, однак євроскептицизм набув популярності через вдале маніпулювання інформацією та фактами популістами та іншими політиками з нової Свропи. Євроскептицизм користується попитом у недавно приєднаних до організації держав. Швидке розчарування, зависокі очікування від організації, а, можливо, дається у знаки минуле під впливом прокомуністичних режимів. Так чи інакше саме ці держави стали основним каталізатором 
поширення ідей євроскептицизму. Опозиція до СС з'явилася разом з СС і знаходилася у латентному стані, однак популісти вивели ії на новий рівень, перевели в активний стан, а Брекзит вивів євроскептицизм у практичну площину. Економічна і міграційна кризи та низка інших проблем, 3 якими стикається $\mathrm{CC}$, стали лише прикриттям. Якщо європейські бюрократи розуміють це, то, передусім, повинні врегулювати питання інформаційної безпеки та сприяти уніфікації економічного та соціального розвитку в усіх державах-членах. А також донести до кандидатів-членів та потенційних членів, що таке Європейський Союз, як він працює, і що це організація, яка не тільки пропонує певні привілеї, але й також очікує певної віддачі.

Висновки та перспективи дослідження. Визначивши та проаналізувавши фактори, що впливають на зростання євроскептичних настроїв, варто зазначити, що будь-які зміни в системі функціонування впливають на позицію громадян до організації. Однак, є чинники, які впливають значно більше, ніж інші. До таких можна віднести прихід до влади у національних урядах популістичних політиків, вплив третіх сторін на політику-держав членів $\mathrm{CC}$, економічна та міграційна кризи. А також найголовнішою причиною є слабкий рівень інформаційної безпеки в ЄС. Тому інституціям $Є С$ необхідно врахувати усі свої прорахунки і якнайшвидше вирішити наявні проблеми. Перспективним напрямком дослідження $є$ детальне вивчення проявів євроскептицизму в інституціях ЄС та в національних урядах, а також визначити роль зовнішніх акторів у поширенні євроскептицизму.

\section{Бібліографічний список/References:}

1. Bickerton C., Guérot U. Perspectives on the future of the EU. 2019. URL: https://www.ui.se/globalassets /ui.se-eng/publications/other-publications/perspectives-on-the-future-of-the-eu.pdf (дата звернення 25.04.2020).

2. Convention determining the State responsible for examining applications for asylum lodged in one of the Member States of the European Communities - Dublin Convention. 2003. URL: https://eur-lex.europa.eu /legal-content/EN/ALL/?uri=CELEX:41997A0819(01) (дата звернення 15.04.2020).

3. De Wilde P. Under what conditions does Euroscepticism flourish? An evaluation of different approaches and empirical findings. 2010. URL: https://www.sv.uio.no/arena/om/aktuelt/aktuelle-saker/2010/deWilde-trial-lecture.pdf (дата звернення 25.04.2020).

4. Egenhofer C. Kaczyński P. The Ever-Changing Union: An Introduction to the History, Institutions and Decision-Making Processes of the European Union. 2011. URL: https://www.researchgate.net/publication/228149154_ The_Ever-Changing_Union_An_Introduction_to_the_History_Institutions_and_Decision-Making_Processes_ of_the_European_Union (дата звернення 26.04.2020).

5. Employment, Social Policy, Health and Consumer Affairs Council (Health). 2020.

URL: https://www.consilium.europa.eu/en/meetings/epsco/2020/02/13/ (дата звернення 27.04.2020).

6. Fine S. All at sea: Europe's crisis of solidarity on migration. European Council of Foreign Relations. 2019.

URL: https://www.ecfr.eu/publications/summary/all_at_sea_europes_crisis_of_solidarity_on_migration (дата звернення 25.04.2020).

7. Hooghe L. Gary M. Sources of Euroscepticism. Acta Politica. 2007. URL: http://garymarks.web.unc.edu/files /2016/09/hooghe_marks_sources-of-euroskepticism.pdf (дата звернення 01.05.2020).

8. How "European" do EU citizens feel? Eurobarometer. European Comission. 2016.

URL: https://ec.europa.eu/commfrontoffice/publicopinion/topics/fs5_citizen_40_en.pdf (дата звернення 27.04.2020).

9. Immigration in the EU. Eurostat. 2015. URL: https://ec.europa.eu/home-affairs/sites/homeaffairs/files/elibrary/docs/infographics/immigration/migration-in-eu-infographic_en.pdf (дата звернення 30.04.2020).

10. Jones T. German AfD parliamentarian could be under Russian influence: report. Deutsche Welle. 2019.

URL: https://www.dw.com/en/german-afd-parliamentarian-could-be-under-russian-influence-report/a-48221119 (дата звернення 03.05.2020)

11. Larsen E., Cutts D. Do Terrorist Attacks Feed Populist Eurosceptics? 2020.

URL: https://ejpr.onlinelibrary.wiley.com/doi/epdf/10.1111/1475-6765.12342 (дата звернення 30.04.2020).

12. Migrant crisis: Migration to Europe explained in seven charts. BBC. 2016.

URL: https://www.bbc.com/news/world-europe-34131911 (дата звернення 01.05.2020).

13. O'Reilly E. How transparent are the EU Institutions? 2018. URL: https://www.ceps.eu/ceps-publications /how-transparent-are-eu-institutions/ (дата звернення 25.04.2020).

14. Public Opinion in The European Union. European Commission. 2014. URL: https://ec.europa.eu /commfrontoffice /publicopinion/archives/eb/eb81/eb81_publ_en.pdf (дата звернення 02.05.2020)

15. Results of the EU28 Survey 2018 on coalition building in the European Union. The European Council of Foreign Affairs. 2018. URL:https://www.ecfr.eu/page/ECFR269_EU_COALITION_EXPLORER_2018_V1.10.pdf (дата звернення 28.04.2020).

16. Risse T. Identity Politics and European Integration: The Case of Germany. 2005.

URL: https://www.cambridge.org/core/books/idea-of-europe/identity-politics-and-european-integration-the-caseof-germany/475ADD44E57C492D972899D22E3334AA (дата звернення 25.04.2020). 
17. Taggart P., Szczerbiak A. The Party Politics of Euroscepticism in EU Member and Candidate States. 2002. URL:https://www.researchgate.net/profile/Aleks_Szczerbiak/publication/237536121_The_Party_Politics_ of_Euroscepticism_in_EU_Member_and_Candidate_States/links/5534fb440cf2df9ea6a4122f/The-Party-Politicsof-Euroscepticism-in-EU-Member-and-Candidate-States.pdf (дата звернення 25.04.2020).

18. The EU economy: 2000 review. European Commission. Directorate-General for Economic and Financial Affairs. 2000. URL: https://ec.europa.eu/economy_finance/publications/pages/publication1716_en.pdf (дата звернення 01.05.2020).

19. The European economy since the start of the millennium. A Statistical Portrait. URL:https://ec.europa.eu/eurostat/cache/digpub/european_economy/bloc-1a.html?lang=en (дата звернення 25.04.2020).

20. Treaty of Rome. European Parliament. 1958. URL: https://www.europarl.europa.eu/about-parliament/en /in-the-past/the-parliament-and-the-treaties/treaty-of-rome (дата звернення 25.04.2020).

21. Vanhoonacker S. Reforming the EU Institution - Challenge for the Council. The rotating Presidency of the Council of the EU. University of the Maastricht. URL: https://www.swp-berlin.org/fileadmin/contents/products /projekt_papiere/sem5_vanhoonacker_schout_sicher.pdf (дата звернення 03.05.2020).

22. Walraed D. What are the trends and dominant drivers of Euroscepticism in the UK, Germany and European Union over the last decade? 2016. URL: https://www.ie-ei.eu/Ressources/FCK/image/Theses/WALRAED_Delfien.pdf (дата звернення 25.04.2020).

23. Wike R., Stokes B. Europeans Fear Wave of Refugees Will Mean More Terrorism, Fewer Jobs. Pew Research Center. 2016. URL: https://www.pewresearch.org/global/2016/07/11/europeans-fear-wave-of-refugees-willmean-more-terrorism-fewer-jobs/ (дата звернення 27.04.2020).

24. Young people and Brexit: a generational divide. 2017. URL: https://blogs.cardiff.ac.uk/wiserd/2017/02/24 /young-people-and-brexit-a-generational-divide/ (дата звернення 28.04.2020).

\section{Yakymchuk M. M. Factors of growing Euroscepticism in the EU}

The article analyzed the main reasons of Euroscepticism. In particular, the author paid attention to the political conditions of Euroscepticism's increasing, and the causes of citizens' distrust in the EU. An interconnection between Euroscepticism and the crises in the EU and how these crises influenced a public opinion was determined.

According to the study, the reasons of Euroscepticism have divided into certain types. Opposition to the EU emerged with since the founding of the EU but was delitescent. During the twentieth century, despite some economic problems, the level of EU support grew steadily until 2007. However, due to the direct or indirect influence of internal and external factors, the opposition to the European Union began to gain momentum. As a result, Euroscepticism moved from a latent state to the implementation of practical tasks, an unprecedented process - the withdrawal of Great Britain from the organization.

Analyzing the statistical indicators of the citizens' position to the EU, as well as the domestic political situation in the organization, the author can conclude that not only significant economic and social problems have contributed to the growth of Euroscepticism. The growth of opposition to the European Union was influenced by the activities of populist parties and movements from Central and Eastern Europe, which began to join the organization after 2004. Eurosceptics from the new Europe uniting with antiEuropeans from the United Kingdom took advantage of the difficult economic situation in the organization and migration challenges. They also conducted a successful information campaign against the EU. As a result, confidence in the Union has dropped significantly. Furthermore, citizens doubt in the effectiveness of the organization was increased.

Key words: Euroscepticism, populism, economic crisis, migration crisis, Brexit. 